\title{
High-frequency Gene Transfer in Pasteurella pseudotuberculosis
}

\author{
By P. C. MCMAHON \\ Microbiological Research Establishment, Porton Down, Salisbury, Wilts
}

(Accepted for publication 2I September 1971)

SUMMARY

A high-frequency donor strain of Pasteurella pseudotuberculosis group A was isolated from a strain which had previously accepted an $F^{\prime} l a c$ episome from Escherichia coli. This donor transferred a variety of genetic markers to $P$. pseudotuberculosis group A recipients. Transfer frequencies of approximately $\mathrm{IO}^{-2} /$ donor bacterium were obtained for early markers from membrane matings at $28^{\circ}$; these frequencies were increased to about $2.5 \times 10^{-1} /$ donor at $37^{\circ}$. Recombinant colonies obtained from membrane matings were free from donor and recipient bacteria but some colonies had more than one recombinant class present. The graded frequencies of marker transfer obtained together with recombinant analysis suggest that markers were transferred linearly.

\section{INTRODUCTION}

Strains of Pasteurella pseudotuberculosis were initially subdivided into serological types I to $\mathrm{V}$ on the basis of agglutination reactions (Thal, 1954). Lipopolysaccharides, specific for each of these types, were chemically characterized by Davies (I958), who redesignated the types $\mathrm{I}$ to $\mathrm{V}$ as serological groups $\mathrm{A}$ to $\mathrm{E}$ respectively. Working with strains of group $\mathrm{D}$, Lawton, Morris \& Burrows (1968) observed that infection of some strains with the $F^{\prime} l a c$ episome, donated by Escherichia coli $\mathrm{K} 12$ (strain 23. IOs), permitted gene transfer from them to recipient strains of group D. Early markers were transferred at a frequency of about $10^{-4} /$ donor bacterium. Rigorous controls were used to prove that gene transfer in fact occurred and that their recombinants were not the consequence of reversion or syntrophic growth of parent strains. This work was extended by Morris \& Burrows (I968), who, by unselected marker analysis, produced a tentative ordering of seven gene loci for strains of group D.

A strain of group A which had acquired $F^{\prime}$ lac from Escherichia coli K I2 (strain 23. IOS) proved to be a fertile donor which transferred unselected markers more efficiently than the group D donor in crosses with a group D recipient strain. Further tests with this group A donor in crosses with recipients of group A showed it to donate early genes at high frequency (about $2.5 \times 10^{-1} /$ donor bacterium) as reported in this paper.

\section{METHODS}

Strains. Escherichia coli K I2 strain 23. IOs $\mathrm{Met}^{-}\left(\mathrm{F}^{\prime} \mathrm{lac}\right)$ was originally supplied to this laboratory by Dr R. C. Clowes. The two starting strains of Pasteurella pseudotuberculosis group A, MREI300 (met-2) and MREI3I7 (nic-2) had been derived in this laboratory by nitrous acid treatment (Kaudewitz, I959) of the prototrophic strain MRE I 224. Strain MRE I 224 (synonym PB I $/+$ ) has been described fully by Burrows \& Bacon (I960). The isolation and properties of the donor strain MRE4OI 8 are described under Results. 
Spontaneously arising auxotrophs were enriched using a modification of the penicillin screening technique (Davis, I948; Lederberg \& Zinder, 1948). Ampicillin was added to cultures to a final concentration of $40 \mu \mathrm{g} . / \mathrm{ml}$. after a $5 \mathrm{~h}$. period of starvation in minimal medium at $28^{\circ}$. After $16 \mathrm{~h}$. incubation in ampicillin at $28^{\circ}$, the bacteria were centrifuged, resuspended in broth and grown to saturation. After a second round of ampicillin treatment the bacteria were plated on complete media. Auxotrophs were characterized by replicating on to defined media containing pools of growth factors (Holliday, 1956). Abbreviations designating genotypes and phenotypes of strains listed in Tables I and 2 follow the recommendations of Demerec, Adelberg, Clark \& Hartman (I968).

Media. Nutrient broth (NB) no. 2 and blood agar base (BAB) no. 2 (Oxoid Ltd, London) were used as complete media. Minimal agar medium (MA), minimal salts solution (MS) and lactose indicator medium were as described in Lawton et al. (1968). Buffer ( $\mathrm{pH} 7 \cdot 6$ ) was (g./1.) $\mathrm{KH}_{2} \mathrm{PO}_{4}, 67 \cdot 5 ;\left(\mathrm{NH}_{4}\right)_{2} \mathrm{SO}_{4}, 7 \cdot 5 ; \mathrm{NH}_{4} \mathrm{Cl}, 7 \cdot 5$.

Plate crosses. Donor and recipient strains were inoculated separately from BAB slopes

Table I. Genotypes of strains of Pasteurella pseudotuberculosis, group A

MRE strain nos.

\begin{tabular}{|c|c|}
\hline Strain & Source \\
\hline$I 300$ & $I 224$ \\
\hline 1317 & 1224 \\
\hline $4018^{*}$ & 1317 \\
\hline 4135 & 1300 \\
\hline 4136 & 1300 \\
\hline 4137 & 1300 \\
\hline 4139 & 1300 \\
\hline 4140 & 1300 \\
\hline 4146 & 1300 \\
\hline $4 I 49$ & 1300 \\
\hline 4150 & 1300 \\
\hline $4 I 5 I$ & 1300 \\
\hline $4153^{\dagger}$ & 1300 \\
\hline $4155 \dagger$ & 1300 \\
\hline 4157 & 1300 \\
\hline $4 I 6 I$ & 1300 \\
\hline 4162 & 1300 \\
\hline $4168+$ & $I 300$ \\
\hline $4 I 74 \dagger$ & 1300 \\
\hline 4194 & 1300 \\
\hline 4176 & 4136 \\
\hline 4177 & 4135 \\
\hline 4178 & 4135 \\
\hline 4179 & 4135 \\
\hline 4180 & 4135 \\
\hline $4 I 8 I$ & 4137 \\
\hline 4182 & 4137 \\
\hline 4183 & 4140 \\
\hline 4184 & $4 r 40$ \\
\hline 4185 & 4153 \\
\hline 4186 & 4153 \\
\hline 4187 & 4153 \\
\hline 4188 & 4153 \\
\hline 4189 & 4153 \\
\hline $419 I$ & 4157 \\
\hline
\end{tabular}

Mutant loci and mutation sites

nic met his pro pyr pur lys arg ilv leu tyr ser

\begin{tabular}{|c|c|c|c|}
\hline+ & 2 & + & + \\
\hline 2 & + & + & + \\
\hline 2 & + & + & + \\
\hline+ & 2 & 22 & + \\
\hline+ & 2 & + & I I \\
\hline+ & 2 & + & + \\
\hline+ & 2 & + & 10 \\
\hline+ & 2 & + & + \\
\hline+ & 2 & + & + \\
\hline+ & 2 & + & + \\
\hline+ & 2 & + & + \\
\hline+ & 2 & + & + \\
\hline+ & 2 & + & + \\
\hline+ & 2 & + & + \\
\hline+ & 2 & + & + \\
\hline+ & 2 & + & + \\
\hline+ & 2 & + & + \\
\hline+ & 2 & 24 & + \\
\hline+ & 2 & + & + \\
\hline+ & 2 & + & + \\
\hline+ & 2 & $2 \mathrm{I}$ & I I \\
\hline+ & 2 & 22 & + \\
\hline+ & 2 & 22 & + \\
\hline+ & 2 & 22 & + \\
\hline+ & 2 & 22 & + \\
\hline+ & 2 & + & + \\
\hline+ & 2 & 25 & + \\
\hline+ & 2 & 26 & + \\
\hline+ & 2 & + & + \\
\hline+ & 2 & 27 & + \\
\hline+ & 2 & + & + \\
\hline+ & 2 & + & + \\
\hline+ & 2 & + & + \\
\hline+ & 2 & + & + \\
\hline+ & 2 & 28 & + \\
\hline
\end{tabular}

* Infected with $\left(F^{\prime} l a c\right)$ from Escherichia coli 23 . Ios and selected for high-frequency donor ability.

$\dagger$ Isolated following u.v. irradiation of strain MRE I 300 . 
into NB and incubated for $I 8 \mathrm{~h}$. at $28^{\circ}$ with rotation. The cultures were diluted ( $\mathrm{I}$ in 9) in fresh NB and incubated with rotation at $28^{\circ}$ for a further $90 \mathrm{~min}$. to bring them into logphase growth. The cultures were diluted in buffer, mixed and plated on selective media. The plates were incubated for 4 days at $28^{\circ}$. Controls consisted of similar numbers of donor and recipient bacteria plated separately on similar media.

Membrane crosses. The log-phase cultures prepared as above, were diluted in NB to give approximately $8 \times 10^{7}$ donor and $2.4 \times 10^{8}$ recipient bacteria $/ \mathrm{ml}$. Equal volumes of donor and recipient bacteria were mixed and a $2 \mathrm{ml}$. sample was filtered through a $13 \mathrm{~mm}$. Millipore membrane (Millipore Corporation, Bedford, Massachusetts, U.S.A.). The membrane was incubated on a BAB plate or, in later experiments, incubated in its holder together with a broth-impregnated disc beneath the membrane. Mating was allowed to proceed for $4 \mathrm{~h}$. at $28^{\circ}$ or for $2 \mathrm{~h}$. at $37^{\circ}$. Bacteria were washed from the membrane, diluted in buffer and plated on selective MA so that approximately $1.5 \times 10^{4}$ donor and $4.5 \times 10^{4}$ recipient bacteria were seeded per plate. The plates were incubated at $28^{\circ}$ for $48 \mathrm{~h}$. Controls consisted of similar numbers of donor and recipient bacteria plated following their separate impingements on to membranes or from the mating mixture just prior to impingement.

Purification and analysis of recombinants. Colonies appearing on the different selective

Table 2. Growth responses of mutants

\begin{tabular}{|c|c|c|}
\hline $\begin{array}{c}\text { Mutant } \\
\text { locus }\end{array}$ & Mutant site(s) & Effective growth factors \\
\hline met $^{*}$ & 2 & Cystathionine (but not homoserine) \\
\hline his & $2 \mathrm{I}, 22,24,25,26,27,28$ & Histidine \\
\hline pro & IO, I I & Proline \\
\hline pyr* & I & Uracil + citrulline (but not uracil + ornithine) \\
\hline pur & 17,25 & Adenine \\
\hline & $19,23,24$ & Adenine or hypoxanthine \\
\hline & $\begin{array}{l}10 \\
15\end{array}$ & $\begin{array}{l}\text { Adenine or guanine } \\
\text { Hypoxanthine or guanine }\end{array}$ \\
\hline lys & 7 & Lysine \\
\hline arg* & 40,42 & Citrulline (but not ornithine) \\
\hline ilv & 3 & Isoleucine + valine \\
\hline & 4 & Isoleucine \\
\hline leu & $4,5,6,7$ & Leucine \\
\hline tyr & $6,7,8$ & Tyrosine \\
\hline ser & $4,5,6$ & Serine \\
\hline
\end{tabular}

* These mutants were tested on the available intermediates in the biosynthetic pathways; growth was also obtained with the later intermediates.

Table 3. The numbers of Pur recombinants obtained from plate crosses of donor MRE $40 \mathrm{I} 8$ and recipient MRE4I40 plated in different proportions

Donor and recipient bacteria were mixed in different proportions, plated on MA+methionine+ $0.01 \% \mathrm{NB}$ and incubated for 5 days at $28^{\circ} .1 \cdot 7 \times 10^{9}$ donor and $1.5 \times 10^{9}$ recipient bacteria, plated separately on similar media and incubated for 5 days at $28^{\circ}$, gave no reversions.

$\begin{array}{cccc}\begin{array}{c}\text { No. of donor bacteria } \\ \text { mixed with } 1 \cdot 5 \times 10^{9} \\ \text { recipient bacteria/ } \\ \text { plate }\end{array} & \begin{array}{c}\text { No. of Pur } \\ \text { recombinants/plate }\end{array} & \begin{array}{c}\text { No. of recipient } \\ \text { bacteria mixed with } \\ 1 \cdot 7 \times 10^{9} \text { donor } \\ \text { bacteria/plate }\end{array} & \begin{array}{c}\text { No. of Pur }{ }^{+} \\ \text {recombinants/plate }\end{array} \\ 1 \cdot 7 \times 10^{5} & \text { Confluent } & 1 \cdot 5 \times 10^{5} & 832 \\ 1 \cdot 7 \times 10^{4} & \text { about } 5000 & 1 \cdot 5 \times 10^{4} & 112 \\ 1 \cdot 7 \times 10^{3} & 714 & 1 \cdot 5 \times 10^{3} & 20 \\ 1 \cdot 7 \times 10^{2} & 164 & 1 \cdot 5 \times 10^{2} & 0\end{array}$



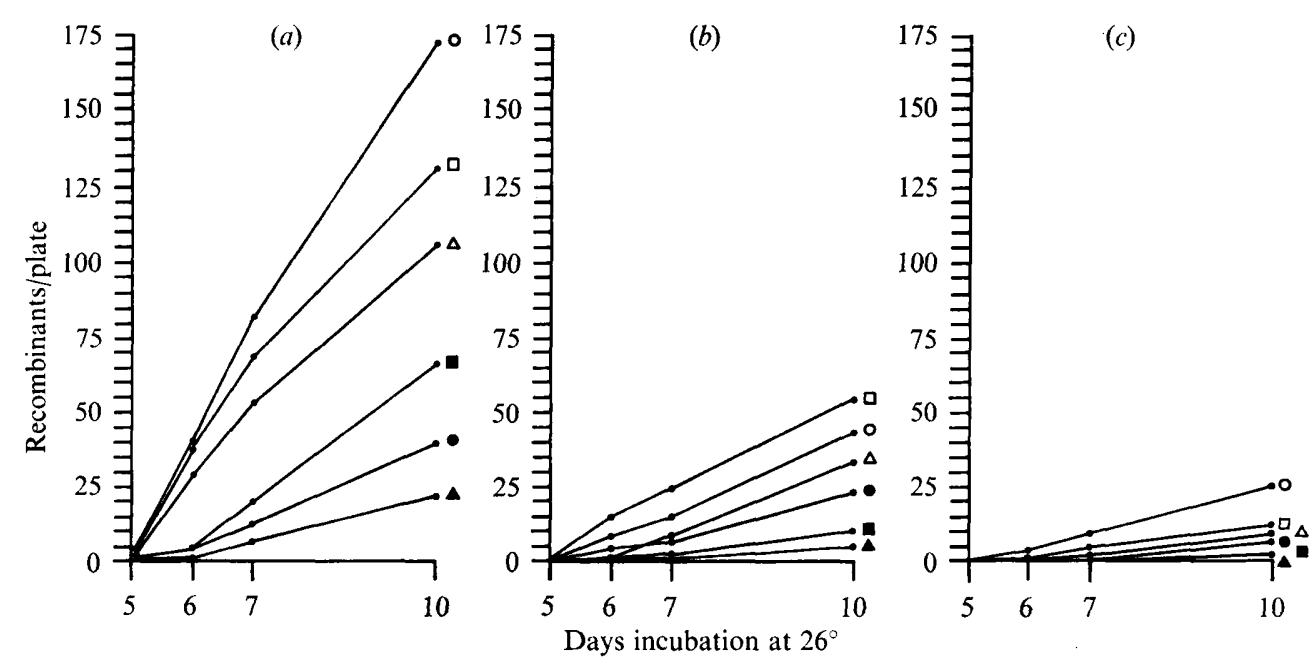

Fig. I. Plate crosses. Effects of numbers of donor bacteria, of the ratios of recipient to donor bacteria plated on selective media and of the period of incubation of the plates on the yields of $\mathrm{Met}^{+} \mathrm{Pro}^{+}$ recombinants from the cross MRE4OI $8 \times$ MRE4I39. Number of donor bacteria per plate: $($ a $) 5.6 \times 10^{3}$; (b) $\mathrm{I} \cdot 9 \times \mathrm{IO}^{3} ;\left(\right.$ c) $9.3 \times \mathrm{IO}^{2}$. Multiplicity of recipient to donor: $\mathrm{O}=\mathrm{I} 0, \square=5, \triangle=2,0=\mathrm{I}$, $\mathbf{\square}=0.5, \boldsymbol{\Delta}=0.2$.

media from plate crosses were always streaked (or plated at low density) on plates of similar media and single colonies from these streaks examined for their requirements. Initially, colonies from membrane crosses were treated in the same way until it was found that samples of young ( 40 to $50 \mathrm{~h}$.) colonies, taken with a finely pointed needle under a dissecting microscope, were invariably pure. This latter method was used to purify most of the recombinants obtained from membrane crosses.

Purified recombinants were analysed for their requirements by replication from a BAB master plate to variously supplemented MA media using a multi-point replicator. Where the compositions of selected recombinant colonies were examined, plates from a low-density plating of the recombinant colony on BAB were replicated (Lederberg \& Lederberg, 1952) to variously supplemented MA media using a velvet pad.

\section{RESULTS}

Isolation of donor strain MRE40I8. Cultures of Escherichia coli 23. IOs and Pasteurella pseudotuberculosis MRE 1317 were mixed and plated on medium selective for $\mathrm{Lac}^{+} \mathrm{Nic}^{-}$ bacteria. The purified colonies obtained were indistinguishable from MRE I 3 I 7 except that they were $\mathrm{Lac}^{+}$. One colony was retained as a dried gelatin pellet (Stamp, 1947) and when crossed with $P$. pseudotuberculosis recipients was able to transfer a number of genetic markers as well as the $\mathrm{Lac}^{+}$episome.

Many cultures of this strain (derived from $\mathrm{Lac}^{+}$single colonies) accumulated in this laboratory and when five were re-tested for fertility one was found to be much more fertile than the rest. Four of the $42 \mathrm{Lac}^{+}$isolates tested proved to be significantly more fertile than the rest. One of the four was retained, given the number MRE4OI8, and used as a donor in the crosses reported here. The highly fertile donor had an enhanced $\mathrm{Lac}^{+}$stability; less than I in 300 colonies was $\mathrm{Lac}^{-}$. 


\section{Features of the mating process}

Plate mating. Mating mixtures containing different proportions of donor (MRE4OI8) and recipient (MRE4I40) organisms were plated on media selective for Pur ${ }^{+}$. The numbers of recombinants obtained are shown in Table 3. Virtually all the donors plated gave rise to a colony from which recombinants could be isolated in crosses in which the donor was the minority parent. Crosses in which the parental ratios were reversed were less fertile.

Crosses in which the parental bacteria were separated by a membrane filter or in which the normal donor was replaced by an $\mathrm{F}^{-} \mathrm{lac}^{-}$derivative of it did not give recombinant colonies on selective media.

Mating on selective plates was studied by plating few bacteria so that the number of initial contacts was low (Fig. I). It is apparent from these results that the greater the multiplicity of recipient to donor, the more recombinants were formed for each of the three levels of donor input; similarly, the greater the donor input for a given multiplicity of recipient,

\section{Table 4. Fertility of mating mixtures of donor MRE4OI 8 and recipient MRE4I 39 held on membranes}

Donor $\left(\mathrm{I} \times 1 \mathrm{O}^{8}\right)$ and recipient $\left(3 \times 1 \mathrm{O}^{8}\right)$ bacteria where impinged as a mixture on to membranes then incubated for $4 \mathrm{~h}$. at $28^{\circ}$ on BAB. The bacteria were washed from the membranes, diluted and plated on selective media. Similar numbers of donor and recipient bacteria, which had been impinged on to separate membranes and incubated for the same period, were washed from the membranes, mixed, diluted and plated. The recombinants were recorded after $40 \mathrm{~h}$. at $28^{\circ}$.

\begin{tabular}{|c|c|c|c|c|}
\hline & \multirow{2}{*}{$\begin{array}{c}\text { No. of donor } \\
\text { bacteria } \\
\text { (thousands)/plate }\end{array}$} & \multirow{2}{*}{$\begin{array}{c}\text { No. of recipient } \\
\text { bacteria } \\
\text { (thousands)/plate }\end{array}$} & \multicolumn{2}{|c|}{$\begin{array}{l}\text { No. of Pro }{ }^{+} \\
\text {recombinants }\end{array}$} \\
\hline & & & Plate I & Plate 2 \\
\hline $\begin{array}{l}\text { Donor and recipient bacteria impinged } \\
\text { together on membrane }\end{array}$ & $\begin{array}{l}9 \cdot 7 \\
4 \cdot 9 \\
2 \cdot 5\end{array}$ & $\begin{array}{r}13 \cdot 7 \\
6 \cdot 9 \\
3 \cdot 5\end{array}$ & $\begin{array}{r}25 \\
10 \\
5\end{array}$ & $\begin{array}{r}24 \\
7 \\
5\end{array}$ \\
\hline $\begin{array}{l}\text { Donor and recipient bacteria impinged } \\
\text { on separate membranes }\end{array}$ & $\begin{array}{r}\text { I I } 8 \\
5 \cdot 9 \\
2 \cdot 9\end{array}$ & $\begin{array}{r}15 \cdot 8 \\
7 \cdot 9 \\
3 \cdot 9\end{array}$ & $\begin{array}{l}0 \\
0 \\
0\end{array}$ & $\begin{array}{l}0 \\
0 \\
0\end{array}$ \\
\hline
\end{tabular}

Table 5. Composition of colonies selected for Pro ${ }^{+}$in the membrane cross MRE 4OI $8 \times$ MRE $4 I 39$

Individual selected Pro $^{+}$colonies were suspended in buffer, serially diluted and plated on BAB. Suitable plates were then replicated with velvet pads to appropriately supplemented MA. In all, 47 colonies were examined, a representative sample of which is shown in the table.

$\begin{array}{ccrrrr}\begin{array}{c}\text { Selected } \\ \text { Pro }{ }^{+} \text {colony }\end{array} & \overbrace{\begin{array}{c}\text { No. } \\ \text { analysed }\end{array}} & \overbrace{\text { Met }^{+}}^{\text {No. of recombinants }} & \text { Met }^{-} & \overbrace{\text { Nic }^{-}}^{\text {No. of parental types }} & \text { Met }^{-} \text {Pro }^{-} \\ \text {I } & 380 & 0 & 380 & 0 & 0 \\ 2 & 328 & 328 & 0 & 0 & 0 \\ 3 & 206 & 206 & 0 & 0 & 0 \\ 4 & 129 & 24 & 105 & 0 & 0 \\ 5 & 119 & 82 & 37 & 0 & 0 \\ 6 & 163 & 0 & 163 & 0 & 0 \\ 7 & 168 & 168 & 0 & 0 & 0 \\ 8 & 112 & 70 & 42 & 0 & 0 \\ 9 & 109 & 0 & 109 & 0 & 0 \\ \text { I0 } & 163 & 33 & 130 & 0 & 0\end{array}$


the greater the number of recombinants formed. It had been observed that donor and recipient bacteria, when plated at low density such as in this experiment, would slowly grow into microscopic colonies. The results shown in Fig. I are consistent with the idea that recombinants arose on selective plates when microscopic colonies of opposite mating types contacted one another.

Membrane mating. Attempts were made to mimic the close contact of donor and recipient bacteria which was believed to be necessary to produce recombinants. The method which gave the most recombinants was to impinge a mixture of donor and recipient on to a Millipore membrane $\left(13 \mathrm{~mm}\right.$.) so that a total of about $4 \times 10^{8}$ bacteria was deposited (Methods). MRE 4OI 8 and MRE 4I 39 were crossed at $28^{\circ}$ for $4 \mathrm{~h}$. in this manner and the numbers of donor and recipient bacteria plated were low enough to exclude mating on these plates in $40 \mathrm{~h}$. The results of this cross (Table 4 ) demonstrate that mating took place exclusively during the $4 \mathrm{~h}$. the donor and recipient were together on the membrane.

Samples were taken at $40 \mathrm{~h}$. from 47 of these selected $\mathrm{Pro}^{+}$recombinants and analysed. Table 5 shows, as examples, the analyses obtained for 10 of them. No donor or recipient bacteria were found in any of the recombinant colonies analysed. Of the recombinants, 23 were $\mathrm{Met}^{-}$and $\mathrm{I} 3$ were $\mathrm{Met}^{+}$. The remaining I I recombinants were mixtures of $\mathrm{Met}^{+}$and $\mathrm{Met}^{-}$; of these, 6 were between Io and $29 \% \mathrm{Met}^{+}$and 5 were between 56 and $88 \% \mathrm{Met}^{+}$. There was no suggestion of persistent instability in the met locus in the bacteria giving rise to these mixed clones; progeny from the mixed clones, when retested in the same manner, were found to be stable. It could be argued that the smaller fraction in these clones segregated from the zygote after the larger fraction had segregated.

\section{Table 6. Frequencies of recombinants selected for single and for double marker transfer in membrane crosses with donor MRE 4018}

Donor $\left(1 \times 10^{8}\right)$ and recipient $\left(3 \times 10^{8}\right)$ bacteria were impinged as a mixture on to membranes and incubated for $4 \mathrm{~h}$. at $28^{\circ}$ on BAB. The bacteria were washed from the membranes, diluted and plated on different selective media so that approximately $1.5 \times 10^{4}$ donor and $4.5 \times 10^{4}$ recipient bacteria were seeded per plate. The recombinants obtained are expressed per $10^{4}$ donor bacteria plated. Control platings showed no revertant colonies.

\begin{tabular}{|c|c|c|c|c|}
\hline \multicolumn{2}{|c|}{ Recipient strains } & \multicolumn{3}{|c|}{ Selected recombinants $/ 10^{4}$ donor bacteria } \\
\hline MRE no. & Genotype & met-2* & Second marker & Both markers \\
\hline 4135 & met-2 his-22 & . & $0 \cdot 2$ & 0.0 \\
\hline 4136 & met-2 pro-II & . & $12 \cdot 8$ & $3 \cdot 5$ \\
\hline 4137 & met-2 pyr-I & . & $10 \cdot 8$ & $2 \cdot 3$ \\
\hline 4139 & met-2 pro-Io & $43 \cdot 5$ & $4 \cdot 4$ & 0.5 \\
\hline 4140 & met-2 pur-I 5 & . & $23 \cdot 7$ & $9 \cdot 3$ \\
\hline 4146 & met-2 lys-7 & $4 I \cdot 8$ & 0.01 & 0.0 \\
\hline 4149 & met-2 $\arg -42$ & . & $6 I \cdot 0$ & $23 \cdot 0$ \\
\hline $4 I 50$ & met-2 pur-I6 & . & $69 \cdot 3$ & $27 \cdot 0$ \\
\hline $4 I 5 I$ & met-2 pur-17 & . & $\mathbf{I} \cdot \mathbf{O}$ & 0.6 \\
\hline 4153 & met-2 ilv-3 & . & $108 \cdot 0$ & $49 \cdot 0$ \\
\hline 4155 & $m e t-2 \arg -40$ & $104 \cdot 8$ & $44 \cdot 0$ & I I 6 \\
\hline 4157 & met-2 pur-I9 & $15 \cdot 24$ & $14 \cdot 2$ & $5 \cdot 2$ \\
\hline $416 I$ & met-2 leu-4 & . & $29 \cdot 4$ & 6.8 \\
\hline 4162 & met -2 tyr -6 & $91-5$ & 0.7 & 0.7 \\
\hline 4168 & met-2 his-24 & $97 \cdot 4$ & 0.3 & 0.3 \\
\hline 4174 & met-2 ser-4 & . & 0.6 & 0.0 \\
\hline
\end{tabular}

* Average: $88 \cdot 6$.

$\dagger l y s-7^{+}$recombinants were obtained when larger numbers of bacteria were plated on selective media. 


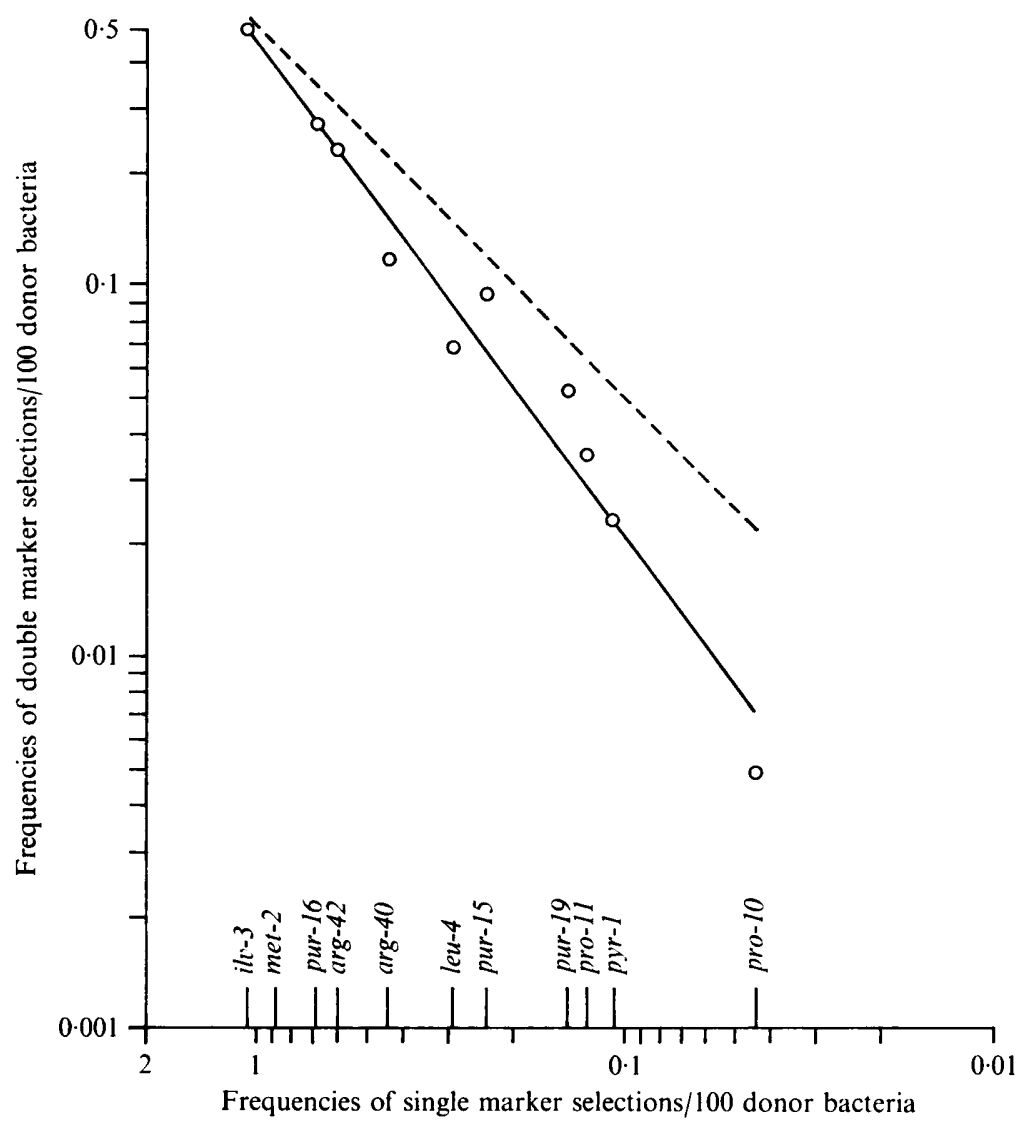

Fig. 2. Frequencies of selection per 100 donor bacteria for single markers (abscissa) and for the same markers in conjunction with met-2 (ordinate) $(O)$. --- represents the expected plot, assuming a 0.5 probability of $m e t-2$ being associated with distal markers in recombinants.

\section{Frequency of gene transfer at $28^{\circ}$}

The membrane mating technique was used to assess the frequency of gene transfer to several doubly marked strains. Selections were made for the second marker and also both markers jointly in each strain. The results in Table 6 show that different markers were transferred with different frequencies, the common marker, met-2, having the second highest frequency of transfer. If the assumption is made that markers are transferred in a linear order as in Escherichia coli (Hayes, 1968), then $i l v-3$ is proximal and the remaining markers distal to met-2. The frequencies of the single marker selections as a percentage of the donor bacteria plated should indicate the approximate order of these markers on the chromosome (Fig. 2). The frequencies of double selections are shown plotted on the ordinate of Fig. 2 and there is a good correlation between the marker position on the abscissa and its frequency of joint selection with met-2. This relationship breaks down for markers more distal than pro-ro, presumably because the number of recombinants for these markers was very low.

Unselected marker analysis of recombinants from nine of these crosses showed lower percentages of unselected 'second' markers among selected met-2 ${ }^{+}$recombinants than of $m e t-2^{+}$in recombinants selected for the 'second' markers. The single exception was for 
selected $i l v-3^{+}$, which had $52 \%$ unselected met-2 $2^{+}$whereas selected $m e t-2^{+}$showed $69 \%$ unselected $i l v-3^{+}$. Of the remaining analyses, the proportion of unselected $m e t-2^{+}$ranged from $44 \%$ of selected leu- $4^{+}$to $28 \%$ of selected $p y r-I^{+}$. These results are consistent with markers being transferred linearly in the order shown in Fig. 2.

\section{Frequency of gene transfer at $37^{\circ}$}

When membranes, impinged with mating mixtures, were incubated at $37^{\circ}$, the frequency of transfer of met-2 was increased from approximately $10^{-2}$ to $2.5 \times 10^{-1} /$ donor bacterium; in addition, recombinants could be obtained for most markers after $2 \mathrm{~h}$. mating.

Strains MRE4I55, 4I94 and 4I76 to 4I9I (Table I) were used as recipients in a series of crosses with donor MRE $40 I 8$ to relate the frequency of transfer of the additional markers to that of the common marker, met-2. The method of crossing and the controls used were the same as for determining frequency of gene transfer at $28^{\circ}$ except that matings were carried out at $37^{\circ}$ and terminated after $2 \mathrm{~h}$. Table 7 shows, in addition to the numbers of recom-

Table 7. Numbers of recombinants obtained with single selections for different markers and their frequencies relative to that for singly selected met-2 in membrane crosses with donor MRE 4018

Donor $\left(\mathrm{I} \times 10^{8}\right)$ and recipient $\left(3 \times 10^{8}\right)$ bacteria were impinged as a mixture on to membranes and incubated for $2 \mathrm{~h}$. at $37^{\circ}$. The bacteria, washed from the membranes and diluted, were plated on different selective media so that approximately $1.5 \times 10^{4}$ donor and $4.5 \times 10^{4}$ recipient bacteria were seeded per plate. The numbers in the table are the sums of colonies on two plates; the results obtained from repeat experiments are shown in sequence.

\begin{tabular}{|c|c|c|c|c|c|c|c|c|}
\hline \multirow{2}{*}{$\begin{array}{l}\text { Recipient } \\
\text { strains } \\
\text { MRE no. }\end{array}$} & \multicolumn{2}{|c|}{ A } & \multicolumn{2}{|c|}{ B } & \multicolumn{2}{|c|}{$\mathrm{C}$} & \multicolumn{2}{|c|}{$\begin{array}{l}\text { Marker frequencies } \\
\text { relative to } m e t-2\end{array}$} \\
\hline & $\begin{array}{l}\text { Selected } \\
\text { marker }\end{array}$ & No. & $\begin{array}{l}\text { Selected } \\
\text { marker }\end{array}$ & No. & $\begin{array}{l}\text { Selected } \\
\text { marker }\end{array}$ & No. & $\mathrm{B} / \mathrm{A}$ & $\mathrm{C} / \mathrm{A}$ \\
\hline 4155 & met-2 & $\begin{array}{l}214 \\
178\end{array}$ & $\arg -40$ & $\begin{array}{r}95 \\
113\end{array}$ & $\dot{.}$ & $\dot{r}$ & $\begin{array}{l}0.44 \\
0.64\end{array}$ & $\dot{r}$ \\
\hline 4176 & met-2 & 307 & pro-II & 75 & his-2I & 12 & 0.24 & 0.04 \\
\hline & & 403 & & 94 & & 12 & 0.23 & 0.03 \\
\hline & & 556 & & 158 & & 30 & 0.28 & 0.05 \\
\hline 4177 & met-2 & 784 & his-22 & 25 & $t y r-7$ & 104 & 0.03 & 0.13 \\
\hline 4178 & met-2 & 620 & his-22 & 22 & ser-5 & 14 & 0.04 & 0.02 \\
\hline 4179 & met-2 & 954 & $h i s-22$ & 25 & $l e u-5$ & 352 & 0.03 & 0.37 \\
\hline 4180 & $m e t-2$ & $57 \mathrm{I}$ & his-22 & 19 & $i l v-4$ & 554 & 0.03 & 0.97 \\
\hline 4181 & met-2 & 260 & pyr-I & 184 & pur-23* & 0 & 0.71 & 0 \\
\hline 4182 & $m e t-2$ & 539 & pyr-I & 174 & his-25 & 21 & 0.32 & 0.04 \\
\hline 4183 & $m e t-2$ & 262 & pur-I 5 & 374 & his-26 & 9 & $\mathrm{I} \cdot 43$ & 0.03 \\
\hline 4184 & $m e t-2$ & 172 & pur-I5 & 267 & $t y r-8$ & 84 & $I \cdot 55$ & 0.49 \\
\hline 4185 & $m e t-2$ & 344 & $i l v-3$ & 584 & his -27 & 9 & $1 \cdot 70$ & 0.03 \\
\hline 4186 & $m e t-2$ & 716 & $i l v-3$ & 658 & leu-6 & 274 & 0.92 & 0.38 \\
\hline & & 496 & & 446 & & 149 & 0.90 & 0.30 \\
\hline 4187 & met-2 & 544 & $i l v-3$ & 820 & pur-24* & 0 & $I \cdot 5 I$ & 0 \\
\hline & & 614 & & 526 & & 0 & 0.86 & 0 \\
\hline $4^{188}$ & $m e t-2$ & 443 & $i l v-3$ & 532 & $\operatorname{ser}-6^{*}$ & 0 & $I \cdot 20$ & o \\
\hline & & 458 & & 465 & & 0 & $1 \cdot 02$ & 0 \\
\hline 4189 & met-2 & 386 & $i l v-3$ & 662 & pur-25 & 179 & $1 \cdot 72$ & 0.46 \\
\hline & & 484 & & 470 & & I 26 & 0.97 & 0.26 \\
\hline $419 I$ & met-2 & 770 & pur-Ig & 29 I & his -28 & 106 & 0.38 & 0.14 \\
\hline & & I 28 & & 58 & & 41 & 0.45 & 0.32 \\
\hline 4194 & met-2 & 350 & leu-7 & I $8 I$ & $\cdot$ & . & 0.52 & . \\
\hline
\end{tabular}

* Recombinants were obtained for these markers when larger numbers of bacteria were plated on selective media. 


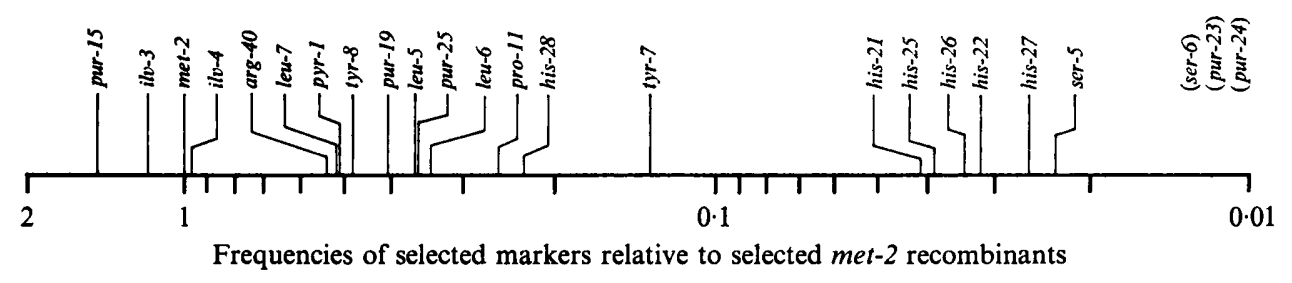

Fig. 3. Frequencies of selected markers relative to selected met-2 recombinants. Recombinants were not obtained in these experiments for markers shown inside brackets.

binants obtained, second and third marker selections expressed as a ratio of the number of selected $m e t-2^{+}$within each cross.

The number of selected $m e t-2^{+}$obtained varied from one cross to another and also between repeats of the same cross. This was presumably due in part to the variation between recipient strains but mostly to the variation in the numbers of donor and recipient plated. However, this variation was usually reflected in the other selections so that the ratios obtained for the same marker in different strains or from repeat estimates in the one cross were in general reasonably consistent. Provided there is no restriction on $m e t-2^{+}$recombination, then these ratios should indicate the relative order of markers to met-2 on the chromosome. The ratios from Table 7 are shown plotted on a log scale in Fig. 3; average ratios are plotted for markers having more than one estimate. Fig. 3 could be regarded as constituting a qualitative map of the chromosome of Pasteurella pseudotuberculosis group A.

\section{DISCUSSION}

The method by which the highly fertile donor strain (MRE4OI8) was derived suggests that a rare event, possibly an integration of $F$ into the chromosome, occurred during its storage at $4{ }^{\circ}$. Its higher fertility, together with an enhanced $\mathrm{Lac}^{+}$stability, distinguished this derivative from other $F^{\prime}$ lac bacteria of the same strain. Unlike the donor strain of Pasteurella pseudotuberculosis (MRE 2027) used by Lawton et al. (1968), treatment of MRE40I 8 with ultraviolet light did not enhance its fertility, a situation analogous to that for $H f r$ strains of Escherichia coli (Hayes, 1953). The highly fertile derivative strain grew less rapidly than the original $F^{\prime} l a c$ strain on MA supplemented with nicotinamide, having become, in addition, partially dependent on methionine. This situation is similar to that reported for $H f r$ derivatives of $E$. coli strain $\mathrm{C}$ (Sasaki \& Bertani, 1965). The same authors defined $H f r$ derivatives of $E$. coli strain $\mathrm{C}$ as those donating their lead markers at frequencies of not less than I/IOO donor bacteria plated. Donor strain MRE4OI 8 would satisfy this definition of $H f r$ in that $m e t-2^{+}$was transferred at approximately this frequency at $28^{\circ}$ and at about $\mathrm{I} / 25$ donor bacteria at $37^{\circ}$.

Throughout this work tests were conducted to ensure that the colonies obtained on selective media from crosses were true recombinants. It seemed improbable that spontaneous reversion of the genes in the donor or recipient strains could have accounted for the large numbers of altered phenotypes recovered from a variety of crosses since no revertants were observed when these strains were separately plated at the concentrations used in the crosses. Likewise, mixed growth or cross-feeding could not account for the occurrence of pure recombinant colonies since these were readily obtained from membrane crosses where mixed growth was minimal. 
Increasing the number of contacts between donor and recipient bacteria increased the yields of recombinants per donor bacterium. If the number of contacts were reduced, the yield of recombinants was also reduced. Normal mating mixtures in different liquid media, held statically or gently rotated, proved to be completely infertile; recombinants were, however, obtained from high-density mating mixtures (of the order of $10^{10}$ bacteria $/ \mathrm{ml}$.) but the yield per donor bacterium was very low. These observations leave little doubt that in Pasteurella pseudotuberculosis group A mating takes place when donor and recipient bacteria are held in close contact. The need for this contact and the absence or instability of mating in liquid media suggests that gene transfer in $P$. pseudotuberculosis group A occurs by a conjugation process analogous to that described for Escherichia coli (Matney \& Achenbach, 1962) and for Salmonella typhimurium (Sanderson \& Demerec, 1965).

The analyses of selected $\mathrm{Pro}^{+}$recombinants obtained from a membrane cross suggested that approximately half the zygotes segregated Met- clones, a quarter segregated $\mathrm{Met}^{+}$ clones and a further quarter segregated clones which were mixtures of $\mathrm{Met}^{+}$and $\mathrm{Met}^{-}$. These mixed clones were of two distinct types, one type tending to $25 \% \mathrm{Met}^{+}, 75 \% \mathrm{Met}^{-}$and the other to $75 \% \mathrm{Met}^{+}, 25 \% \mathrm{Met}^{-}$. These mixed clones could be explained, in terms of the observations on pedigree analysis of Escherichia coli zygotes (Anderson, 1958), by the minor component segregating about one division after the major component had segregated.

The proximal marker, met-2, has a probability of less than 0.5 of being associated with distal markers in recombinants; the more distal the marker is from met-2, the lower is its probability of being associated with it (Fig. 2). Reduction of proximal marker incorporation in recombinants has also been observed for Salmonella typhimurium (Johnson, Krauskopf \& Baron, I965; Dubnau \& Stocker, 1967). Reasonable conformity was obtained for the order of transfer of certain markers when crosses were conducted at $28^{\circ}$ and $37^{\circ}$. Of the eight markers which were common to both tests, ilv-3, met-2, arg-40, pur-I9, pro-II, his-22 transferred in the same relative order in the two experiments. Mutants with similar requirements tended to map in the same region (see Figs. 2, 3). All the His mutants, except his-28, map as near distal markers and ser-4 (Table 6), ser-5 and ser-6 (unplaced) map as distal markers. The main exception is $t y r-7$ and $t y r-8$, which would appear to be well separated.

The fertility system reported here is one in which a high-frequency donor strain transfers its genetic information in an orientated linear manner to recipient bacteria. Since the proximal marker met-2 was inherited with a variety of other markers and recombinants could be obtained for all the genes examined, it is probable that these genes are on one linkage group and their frequencies of transfer, as shown in Fig. 3, can be used to formulate a qualitative map of the genome. These conclusions differ from those of Lawton \& Stull (I97I), who, because they did not obtain proximal markers in association with other markers in their recombinants, concluded that there were two or more linkage groups in Pasteurella pseudotuberculosis group D. It is possible that groups A and D differ in this respect.

Preliminary results from interrupted mating experiments suggest that met-2 has an intercept at about $30 \mathrm{~min}$. on the time scale and unselected ser-6 (among selected met-2 $\mathbf{2}^{+}$) an intercept at about $100 \mathrm{~min}$.

I am indebted to Dr T. W. Burrows for most helpful discussion and to Mr P. E. Stone for his excellent technical assistance. 


\section{REFERENCES}

ANDERson, T. F. (1958). Recombination and segregation in Escherichia coli. Cold Spring Harbour Symposia on Quantitative Biology 23, 47-58.

Burrows, T. W. \& BACON, G. A. (1960). V and W antigens in strains of Pasteurella pseudotuberculosis. British Journal of Experimental Pathology 6r, 38-44.

Davies, D. A. L. (1958). The smooth and rough somatic antigens of Pasteurella pseudotuberculosis. Journal of General Microbiology $18,118-128$.

DAvis, B. D. (1948). Isolation of biochemically deficient mutants of bacteria by penicillin. Journal of American Chemical Society 70, 4267.

Demerec, M., Adelberg, E. A., Clark, A. J. \& Hartman, P. E. (1968). A proposal for a uniform nomenclature in bacterial genetics. Journal of General Microbiology 50, I-I4.

Dubnau, E. \& Stocker, B. A. D. (1967). Behaviour of three colicine factors and an R (drug-resistance) factor in Hfr crosses in Salmonella typhimurium. Genetical Research 9, 283-297.

HAYES, W. (1953). The mechanism of genetic recombination in Escherichia coli. Cold Spring Harbour Symposia on Quantiative Biology $\mathbf{1 8}, 75-93$.

HAYES, W. (1968). The Genetics of Bacteria and Their Viruses, 2nd edn. Oxford and Edinburgh: Blackwell Scientific Publications.

Holliday, R. (1956). A new method for the identification of biochemical mutants of micro-organisms. Nature, London $\mathbf{1 7} 8,987$.

Johnson, E. M., KraUSKopf, B. \& BARON, L. S. (1965). Genetic mapping of Vi and somatic antigenic determinants in Salmonella. Journal of Bacteriology 90, 302-308.

KaUdewitz, F. (1959). Production of bacterial mutants with nitrous acid. Nature, London 183, 1829-I830.

Lawton, W. D., Morris, B. C. \& Burrows, T. W. (1968). Gene transfer in strains of Pasteurella pseudotuberculosis. Journal of General Microbiology 52, 25-34.

Lawton, W. D. \& Stull, H. B. (I97I). Chromosome mapping of Pasteurella pseudotuberculosis by interrupted mating. Journal of Bacteriology 105, 855-863.

LEDERBERG, J. \& LeDERBERG, E. M. (1952). Replica plating and indirect selection of bacterial mutants. Journal of Bacteriology 63, 399-406.

LEDERBERG, J. \& ZINDER, N. (1948). Concentration of biochemical mutants of bacteria with penicillin. Journal of American Chemical Society 70, 4267-4268.

MATNEY, T. S. \& ACHENBACH, N. E. (1962). A comment on the fertility of $\mathrm{F}_{2}$ donor types of Escherichia coli K 12. Biochemical and Biophysical Research Communications 9, 285-287.

Morris, B. C. \& Burrows, T. W. (1968). Gene transfer studies with Pasteurella pseudotuberculosis. International Symposium on Pseudotuberculosis, Paris 1967. Symposia Series - Immunobiological Standardization 9, 275-284.

Sanderson, K. E. \& Demerec, M. (1965). The linkage map of Salmonella typhimurium. Genetics 51, 897-913.

SASAKI, I. \& BERTANI, G. (I965). Growth abnormalities in Hfr derivatives of Escherichia coli strain C. Journal of General Microbiology 40, 365-376.

STAMP, LORD (1947). The preservation of bacteria by drying. Journal of General Microbiology 1, 25 I-265.

ThaL, E. (1954). Untersuchungen über Pasteurella pseudotuberculosis. Lund, Sweden: Berlingska Boktryckeriet. 